\title{
What do we expect from an ombudsman? Narratives of everyday engagement with the informal justice system in Germany and the UK
}

\author{
Naomi Creutzfeldt"
}

\begin{abstract}
This paper looks at expectations people have of informal justice mechanisms through a rich empirical dataset of 2,775 recent ombudsman users in Germany and the UK. In a cross-cultural comparison, the ombudsman as a model of justice is explored. Not much is known about people's expectations of the ombudsman model; this paper starts to fill the gap. Four roles became apparent in cross-cultural narratives in the dataset: people who interact with ombudsmen expect them to be interpreters, advocates, allies and instruments. The identified roles are largely common to both countries, but in some aspects they show national specificities. These national specificities are seen mainly in the use of language; in Germany, it is more legalistic in comparison to the UK. I argue that this might be related to what has been described as the general legal culture of each country and the institutional set-up.
\end{abstract}

\section{Introduction}

This paper explores people's expectations of an ombudsman ${ }^{\mathrm{I}}$ in a cross-cultural comparison. Questions guiding this exploration are: What does the public expect from an ombudsman? What informs these expectations, and do they vary according to the type of ombudsman or by country?

This paper takes individuals' attitudes towards an ombudsman as a starting point, and explores narratives of similarities and differences. It is based on a rich dataset, consisting of 2,775 responses to surveys, collected over six months (September 2014-March 2015) from recent users' of ombudsman services in Germany and the UK. Four roles are identified in people's general attitudes towards this system of everyday justice.

An ombudsman offers a form of alternative dispute resolution (ADR) that provides consumers with a pathway to resolve their complaints about goods and services (private-sector ombudsmen) and provides citizens with a means to resolve their complaints about public-service providers (public-sector ombudsmen). The ombudsmen are positioned outside the formal legal system, but are part of the realm of administrative and civil justice (Adler, 20I2, p. 3i; Creutzfeldt, 20I4, p. 528). Over recent decades, ombudsmen have grown into being a substantial and permanent feature relating to the legal systems in many countries around the world. Originally a part of constitutional accountability systems (Seneviratne, 2002), ombudsmen are now also firmly part of the private civil justice realm

* ESRC Research Fellow, Lecturer in Law, Faculty of Social Sciences and Humanities, University of Westminster, 4-I2 Little Titchfield Street, London, WIW 7UW. E-mail: n.creutzfeldt@westminster.ac.uk. This work was supported by the Economic and Social Research Council (ESRC) (grant number ES/Koo820X/I). I am very grateful to Petra Mahy, Agnieszka Kubal, Christina Cook, Kirsten McConnachie and Fernanda Pirie for helpful feedback in the process of writing this paper. I also want to thank the reviewers for insightful suggestions to improve the paper. An earlier version of this paper was presented at the SLSA annual conference in Warwick 3I March-2 April 2015.

I The term 'ombudsman' is used not to imply gender; rather it is how these bodies call themselves in Germany and the UK. 
(Hodges et al., 20I2), performing an important independent complaints-handling function. This positions the ombudsman as a significant ADR pathway, outside the courts.

The rapid expansion of the ombudsman enterprise (Buck et al., 20II) across the public and private sectors (what Harlow and Rawlings (2009) have termed ombudsmania) has brought with it a growing variety of institutional and jurisdictional arrangements, operational styles and decision-making processes. It offers distinct possibilities for the study of the relationship between decisionmaking practices on the part of ombudsmen and perceptions of justice on the part of users across different jurisdictions and cultures.

The paper is divided into six parts. Section I comprises an introduction to the ombudsman in public and private settings, followed by Section II, an outline of the informal justice system as understood in this paper. The methodology is covered in Section III, then Section IV presents the data of recent users of ombudsmen. Section V compares people's expectations of the informal justice system and Section VI concludes the paper.

\section{Ombudsmen as an informal justice system}

The informal justice systems, as discussed in this paper, include processes of justice that are distinct from the formal legal system, as implemented through the courts. Practices of ADR take place alongside the national court system in most countries. I choose to keep these loose categories of formal and informal, distinguishing ADR from courts, to be able to think about justice broadly (Sternlight, 2002, p. 304). The ombudsman is an institution of informal justice systems. Whereas the formal processes of justice have been explored extensively, gaps remain in understanding of models of informal justice systems in Europe, especially ombudsmen (Hodges et al., 20I2).

Public-sector ombudsmen are part of the constitutional and administrative justice landscape in many countries across the world. The model originated in Sweden in I809. In the UK, the parliamentary ombudsman was established as a 'system of justice...modelled not on the domestic common law courts but on the inquisitorial approach adopted from further afield. The chief characteristics of this institution were to be impartial and informal' (Abraham, 20II). An ombudsman is not bound by the formalities of the court system and the procedures are more flexible. They are based on an inquisitorial rather than an adversarial method of fact-finding and the outcomes lead to recommendations rather than binding judgments.

Private-sector ombudsmen developed much later than their established relatives in the public sector (Creutzfeldt, 2013). They were created because of the need for access to justice for low consumer complaints about goods and services. Different countries have different models of ombudsmen (Hodges et al., 2012). Recent EU-wide legislation on consumer ADR (Directive 2013/ II/EU) requires standardisation of the availability and the quality of ADR bodies (such as ombudsmen). The directive was implemented in July 2015 (Hodges and Creutzfeldt, 20I3). There are some consumer sectors that are subject to EU-wide regulation with mandatory ADR coverage, such as financial services, energy and telecommunications. This paper focuses on established ombudsmen models in Germany and the UK. Similarly to the public-sector ombudsmen, the private-sector ombudsmen reach decisions according to what is deemed fair and reasonable (over and above strictly legal questions). This approach offers great flexibility with provision of individual justice, which a formal legal process might not be able to match (Kirkham, 20I6). Generally speaking, their processes are different from that of a court in that neither public- nor private-sector ombudsmen can issue legally enforceable decisions (often referred to as lack of teeth'). ${ }^{2}$ They do not test evidence in adversarial settings and do not conform to judicial expectations. In these ways, the ombudsman process is distinct from the formal justice system.

2 The decisions of private-sector ombudsmen are usually binding on the member business. 

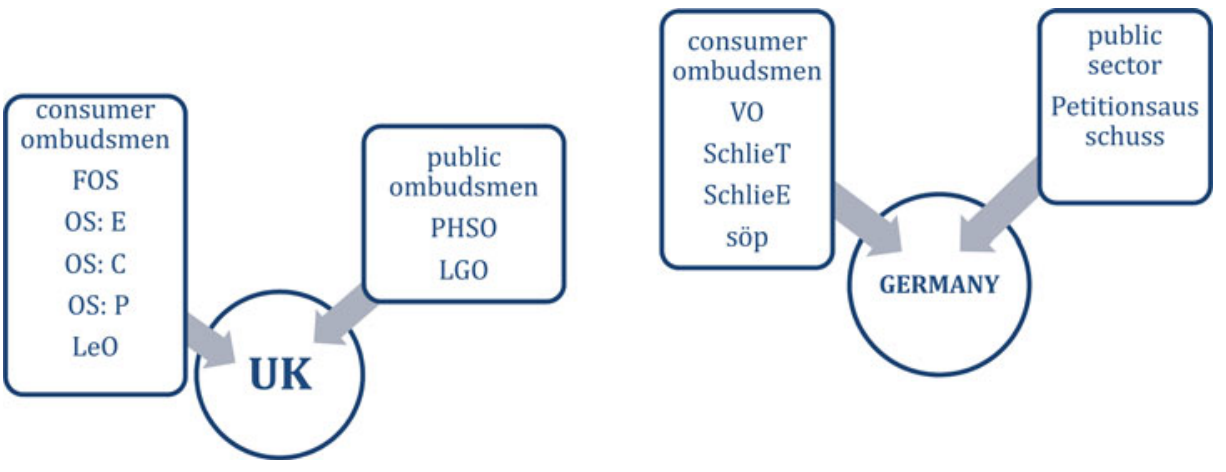

Figure $\mathbf{I}$

ADR bodies in the study.

Acronyms UK: Financial Ombudsman Service (FOS); Ombudsman Services: Energy (OS:E);

Ombudsman Services: Communications (OS:C); Ombudsman Services: Property (OS:P);

Parliamentary and Health Service Ombudsman (PHSO); Local Government Ombudsman (LGO). Acronyms Germany: Versicherungsombudsmann (VO) (insurance); Schlichtungsstelle Telekommunikation (SchlieT) (telecoms); Schlichtungsstelle Energie (SchlieE) (energy); Schlichtungsstelle für den öffentlichen Personenverkehr (söp) (transport).

\section{Methodology}

This paper is based on a dataset that I collected in fourteen different ombudsman schemes in three different European countries (UK, France and Germany). For the purpose of this paper, the UK and Germany have been chosen as case-studies because the French responses did not provide enough material to compare with the other two countries. The UK and German dataset consists of 2,775 responses to customer satisfaction surveys. The sample of ombudsmen schemes was a combination of public and private sector in each country (see Figure I). Between September 2014 and March 20I5, online and paper-based surveys were sent out by ombudsmen staff to consumers who had been through their complaints procedures. This approach had several advantages. The ombudsmen staff sent out the surveys, reflecting the number and type of cases completed, by month. This allowed me to respect the anonymity of the consumer and prevent selection bias. In total, I,465 participated in the German sample and I,3 Io participated in the UK sample. The average response rate was 22 per cent.

The survey contained both closed and open-ended questions. Closed questions were focused on perceptions of procedural justice and the legitimacy of the ombudsmen and (only) provided the demographic data in this paper. The quantitative datasets have been used to produce individual ombudsman reports ${ }^{3}$ and a paper that discusses procedural justice and decision acceptance of recent users of ombudsmen (Creutzfeldt and Bradford, 20I6). Open-ended questions asked about people's expectations of the ombudsmen and reasons for contacting them. This set of questions informs the qualitative analysis of 2,775 responses in this paper. Initially, the open-ended questions were added as an experiment to see whether people would choose to take time to elaborate on their experiences, as well as ticking boxes for the quantitative series of questions. The unexpected richness of the responses enabled me to explore, distinguish and compare respondents' attitudes towards ombudsmen. The responses reflected people's complex attitudes to justice.

〈https://www.law.ox.ac.uk/trusting-middle-man-impact-and-legitimacy-ombudsmen-europe/project-reports〉. 
Ombudsmen and ADR bodies come in many different shapes and sizes, have different procedures and deal with different types of complaints. Generally, in an ombudsman procedure, the citizen does not have legal representation. ${ }^{4}$ According to shared rules throughout the EU about when people can contact an ombudsman, all citizens will have already had to deal with either a company (privatesector) or a local authority (public-sector) internal complaints procedure. This means that people have spent weeks or months trying to sort out their complaint before they qualify to approach an ombudsman.

\subsection{Public-sector ombudsmen: types of complaints}

Public-sector ombudsmen look at grievances citizens have about public bodies. They have different jurisdictions and, within these, are responsible for various types of citizens' complaints. This study concerns three public-sector ombudsmen: the Local Government Ombudsman (LGO) 5 and the Parliamentary and Health Service Ombudsman $(\mathrm{PHSO})^{6}$ in the UK; and the Petitionsausschuss 7 (committee on petitions) in Germany.

The LGO, created by the Local Government Act in I974, processes complaints about local councils and some other authorities and organisations, including education admissions appeal panels and adult social care providers (such as care homes and home-care providers). It is a free service for the citizen. The LGO's job is to investigate complaints in a fair and independent way, without taking sides. ${ }^{8}$ It considered I I,725 complaints and enquiries in 20I3-20I4, of which 6,880 cases were investigated.

The role of the PHSO is to investigate complaints from individuals who consider they have been treated unfairly or have received poor service from government departments and other public organisations and the NHS in England. The PHSO received 27,566 enquiries in 2013-2014 and assessed 7,760 complaints (6,093 about the NHS and I,658 about a government organisation) and completed 2,I99 investigations.

The Petitionsausschuss in Germany, also called the 'Parliament's seismograph' on its website, ${ }^{9}$ has a mandate to examine the impact of legislation on ordinary people (Deutscher Bundestag, 2015). Any letters with requests or complaints addressed to the Bundestag (the lower house of the German parliament) are passed on to the Committee, which examines and deliberates on these petitions. This makes it a 'seismograph', which records the mood among the population, on the basis that citizens are best placed to say whether legislation is achieving its intended aims or causing new problems and therefore needs to be reviewed critically, or whether the Bundestag should take action to address a particular concern. In 2015, there were 15,325 petitions filed by individuals (Deutscher Bundestag, 2015).

\subsection{Private-sector ombudsmen: types of complaints}

Compared with public-sector ombudsmen, most private-sector ombudsmen are still fairly recent institutions (Hodges et al., 20I2). Private-sector ombudsmen look at grievances that consumers

4 This varies across countries and ombudsmen: for example, in Germany, it is quite common to have a lawyer involved for insurance and energy complaints, whereas, in the UK, it is rare to have a lawyer involved.

5 〈http://www.lgo.org.uk/〉.

6 〈http://www.ombudsman.org.uk/>.

7 Germany has no public-sector ombudsman as such; the German equivalent is the Petitionsausschuss. It has similar functions to the UK public-sector ombudsmen discussed in this paper, but with a comparatively limited mandate.

8 Types of complaints include: education and children; benefits and tax; planning and development; adult care services; housing; corporate and other services; highways and transport; environmental, public protection and regulation.

$\langle$ http://www.bundestag.de/htdocs_e/bundestag/committees/ao2〉. 
have with businesses about faulty goods and services. They are set up in different ways to their publicsector counterparts and cover different sectors and areas of complaints. Figure I provides an overview of the ombudsmen examined in this study. The following provides a brief overview of the Financial Ombudsman Service (FOS) and Ombudsman Services (OS) in the UK and the söp (Schlichtungsstelle für den öffentlichen Personenverkehr) ${ }^{\text {IO }}$ in Germany. All of these services are free of charge to the consumer. The different models have different funding structures but, for the most part, participating companies bear the cost of the procedures, either with a set-fee structure or on a 'polluter pays' basis. As I have explained elsewhere, for example:

'OS is funded by industry on a "polluter pays" basis, through a combination of subscription and case fees. Case fees are the charge to consider a complaint, which is not dependent on outcome. This acts as an incentive for companies that is, by improving their customer service and resolving more complaints in-house they stand to minimize disputes referred to OS and thus pay less case fees.' (Creutzfeldt, 2014)

The FOS ${ }^{\text {II }}$ was set up under the Financial Services and Markets Act 2000 to resolve individual disputes between consumers and financial businesses. The types of complaints covered are PPI (payment protection insurance), banking, insurance, mortgages, credit cards and store cards, loans and credit, payday lending and debt collecting, pensions, savings and investments, hire purchase and pawnbroking, money transfer, financial advice and stocks, shares, unit trusts and bonds. In 20I3-20I4, there were 2,357,374 initial enquiries and complaints from consumers, and around one in five progressed into a formal dispute.

$\mathrm{OS}^{12}$ is a body that provides dispute resolution for the communications, energy, property and copyright licensing industries. Across all industry sectors, OS received I73,664 initial contacts in 20I3-20I4, and resolved 28,640 cases. More specifically, taking the energy sector as an example, 26,760 energy complaints were handled in 2013-20I4. The types of complaints were mainly billing ( 82 per cent), transfers to other providers ( 13 per cent) and sales (3 per cent).

The söp was founded in December 2009 and deals with complaints about travel by train, bus, aeroplane and ship. In 2013, the söp completed 3,576 cases. For the present study, only airline disputes are considered, which were dealt with online (Creutzfeldt and Berlin, 2016). These are mainly about delays, cancellation and baggage. In 20I4, the söp dealt with 4,8I3 airline complaints.

This overview of the types and number of complaints public and private ombudsmen deal with in different sectors highlights the diversity in the landscape of dispute resolution in the informal justice system (Hodges et al., 20I 2; Berlin, 20I4).

\subsection{The nature of the sample}

The limitations of this approach have to be kept in mind when discussing the results. They are twofold: first as regards the sample and second as regards the choice of comparison between the public and private sectors.

The sample consists of a specific group of ombudsman users: those who had been through the complaints procedure and chose to be part of the study. There is the possibility that people who are upset with the process are more likely to respond to a survey than people who are satisfied. Further, public and private ombudsmen look at very different types of complaints. My study compared people's experiences with the overall management of their complaint; it did not explore

Io Conciliation body for public transport, 〈https://soep-online.de/〉.

I I 〈http://financial-ombudsman.org.uk/〉.

$\langle$ http://www.ombudsman-services.org/\#〉. 
the detail of individual complaints. There is a difference in the contractual relationship between a customer and a supplier of goods and services and the more complex relationship between the citizen and the state. This study looks at general attitudes and detects patterns in complainants' expectations; it is not an in-depth case-by-case analysis.

However, as this is the first study of its kind with a unique dataset on public and private ombudsman users, across countries, the data provide a starting point from which to understand people's expectation of the ombudsman system. In other words, this paper is setting the scene by exploring the field and identifying shared attitudes; it is not looking at possible sector-specific characteristics. Nonetheless, the paper does identify certain national differences, between German and UK ombudsman users.

\section{Recent users of ombudsmen}

Regarding the demographics, although the responses of the users of ombudsmen in this study vary, clear patterns can be identified. The majority of respondents of the survey sample of 2,775 in Germany and the UK are (on average): male (60 per cent), between 35 and 55 years old (75 per cent), educated (55.3 per cent) and (in the UK) White (77.4 per cent). These findings resonate with Hertogh's results in his paper on public-sector ombudsmen and trust in the Netherlands: 'although the ombudsman aims to reach all types of citizens, most complainants are highly educated, white-collared, politically interested men' (Hertogh, 2013). One contribution of the dataset in this study is that it is evident that public- and private-sector ombudsmen in Germany and the UK largely share the same demographic profile. However, a few nuances were detected. Looking at the overall figures of this sample, people who go to a private-sector ombudsman are more likely to be employed and have a higher level of education than those who approach a public-sector ombudsman. The user age varies slightly according to type of scheme. Generally speaking, the public sector has a larger number of older users and a slightly wider-spread ethnic demographic than the private sector. Data on ethnicity could only be gathered in the UK. In Germany, questions about ethnicity are not permitted. I conclude from the sample that the publicsector ombudsmen reach a wider demographic than the private-sector ones.

\subsection{Shared narratives and role expectations of ombudsmen}

To explore patterns of attitudes to the ombudsmen empirically in the datasets, I initially read through the open-ended questions in two sets of data: the PHSO (public sector) and the FOS (private sector). The survey questions were: 'Could you briefly state, in your own words, what the problem was you contacted the ombudsman about?' and 'What did you expect the ombudsman to do for you?' In the search for narratives within the answers, my own questions were: (I) What do people expect an ombudsman to do for them? (2) In people's expectations of an ombudsman, what role does the law play, if any? (3) What do respondents say about justice, more generally?

The narratives in the open-ended questions indicate differences between expectations of public and private ombudsmen. People approaching a public-sector ombudsman are mainly interested in the public body's accountability and need the ombudsman to remind the public body of this. In the private sector, consumers seek 'a quick fix' to their problem from the ombudsman, which is typically financial compensation. The expectations of an ombudsman, however, are very similar in both sectors and across countries. In the following sections, I showcase the data that led to both findings, first the different expectations of public- and private-sector ombudsmen, and second the shared narratives across public and private, and national divide. 


\subsubsection{Public-sector ombudsman: seeking accountability}

Expectations of people who approach the public-sector ombudsman are, in line with the aim of this type of institution, to ensure public accountability for services that are not being provided as they are supposed to. Here, the difference in mandate and procedures between the British ombudsmen (PHSO and LGO) and the German Petitionsausschuss does not allow a detailed analysis of differences or similarities beyond public accountability. The answers to the question 'What did you expect the ombudsman to do for you?' are presented below.

Typical expectations of people approaching the Petitionsausschuss ${ }^{\mathrm{I3}}$ related to public acknowledgement of problems, issues of human rights and corruption. A typical example from this small dataset (twenty-five respondents, made up of fifteen males and ten females) was the following:

'I had hoped for my complaint to turn into a public debate and that it would grab the attention of the lawmakers. I hoped for a change in laws and help for me and for fellow citizens who have suffered the same problem but lack the courage to act. ... to get a clear stand that corruption and fraud are not legal in Germany.'

The LGO and PHSO respondents shared expectations of accountability that the ombudsman process would set things right not only for them, but also for others, to raise matters of public interest and get an apology. Some examples from the LGO dataset (3I4 respondents: 58.9 per cent male; 40.5 per cent females, 8 r.6 per cent White British) and the PHSO dataset (265 respondents: 54.8 per cent male; 45.2 per cent female, 77.3 per cent White British) were as follows:

'I expected the ombudsmen to address the issues with the planning department; make them accountable for their mistakes so that the same problems didn't arise again; ... insist that questions were answered and not just ignored.'

'I expected the ombudsman to conduct a thorough investigation into my concerns so that lessons could be learned ... take my evidence and that of the Council to evaluate whether maladministration had occurred.'

Summing up, public-sector ombudsmen are expected to improve the way things are done for both the citizen and also for others; to get the authority to apologise; to flag a problem of general interest that should be in the public debate; and to get the authorities to change their behaviour.

\subsubsection{Private-sector ombudsman: seeking individual redress}

By contrast, the data showed that expectations of people who approach the private-sector ombudsman are more often driven by hopes of fast individual dispute resolution and financial compensation. A combination of responses from consumer ombudsmen in Germany and the UK show similar expressions of expectations from the respective ombudsmen.

Some examples of the German dataset underline the expectations of fast, cheap and easy individual redress. Respondents expect:

'that he [the ombudsman] should put things right and help me enforce my rights, at no cost to me and in a fast and efficient manner.'

'that he [the ombudsman] solves the problem with the insurance, and convinces them that I have the law on my side.'

I3 I translated the German data into English. 
Similarly, the UK respondents expect the ombudsman to:

'force [the company] to make the payments owed promptly, with a small compensation amount.'

'act on my [the consumer's] behalf, hopefully with some "teeth" or power behind them, to force [the company] to finally do what any self-respecting company trading within the UK should do, i. e. treat its customers with some level of service \& respect.'

Private-sector ombudsmen are expected to get consumers' money back or compensation; to be an enforcer for the individual; and to provide fast, positive results. As one of the respondents pointed out:

'In my case I got the impression that the pure fact that I asked the conciliation body for "help" led to my "opponent" taking me seriously!! In other words, in this country [Germany] arguments only have limited power, it seems more important to have the right "letterhead", to have a "competent" sender.'

Despite consumers creating a sector-specific narrative, however, I found distinctions when probing further.

The data show quite clearly that, despite individuals contacting ombudsmen for different purposes, both German and UK respondents have common role models in mind that they expect the ombudsmen to fulfil. In other words, the data exposed demands for ombudsmen to take on different roles as the middleman between a 'small' individual and a 'large' company or institution. In both private and public settings, there was a desire to be heard and treated fairly ${ }^{14}$ and to have a competent partner to sort out the problem. The narratives indicate four distinct roles that an ombudsman is expected to perform during the individual's complaints journey.

\subsection{The roles (expected) of ombudsmen}

The narratives within the dataset that uncovered people's expectations of an ombudsman translated into four normative roles:

- Interpreter: to help me understand what it's all about

- Advocate: to hand over my problem

- Ally: to share the responsibility

- Instrument: they have the right tools to help me.

These roles became apparent in the dataset, creating a pattern of how people think and talk about the ombudsmen.

These four roles are not absolutely separate from one another. As with most studies trying to make sense of everyday human interactions, there are no clear boundaries. This means that the role expectations may overlap throughout an individual's complaint journey. What is common to these roles is that they are expected to even out the power imbalance between the 'small' individual and the 'big' company or council. The four roles are outlined below.

\subsubsection{Ombudsman as interpreter}

The complainant needs the ombudsman to break through communication barriers. This role requires the ombudsman to translate and advise both ways; first, to the consumer to clarify what the company

I4 These findings resonate with the four key criteria of procedural justice: voice, standing, neutrality and respect (Lind and Tyler, I988). 
actually means and, second, to find the right words for the consumer to respond to the company. In many ways, this is a basic information, signposting and communication service. Some responses from the dataset explain this role:

'I expected the ombudsman to contact [the company] and find out just what had happened ... as I was being fed rubbish by them!! I need help to understand my rights and their enforcement and that my concerns are heard and taken seriously.'

'I wanted to get the government department to reply to my complaint letter, I hoped they could get both companies to actually listen and properly investigate what was causing the delays so someone could take responsibility and finally sort it out, rather than just expecting me to pay money that I didn't actually owe at all. Neither company would listen to me and just kept telling me it was the other company's fault.'

'I hoped that my problem would be brought to the attention of [the company] more forcefully than I was able to do. I felt as if I was just a number in the scheme of things and I should wait to be told at their convenience. I hoped they could provide an answer and a time scale to bring this to an end.'

'I expected an independent view of my complaint and advice of the avenues available to me to pursue it further.'

'I have been on hold with [the company] for 40 minutes on many occasions and in the end I realised that I haven't got time for it to go any longer. All I was hoping for the Ombudsman to do was to tell them to close my account - [the company] has ignored all of my emails and messages on Facebook so I had no other means of contacting them. [The company] owed me €270.'

\subsubsection{Ombudsman as advocate}

The complainant needs the ombudsman to help reach his or her goal and is happy to hand over the case. The role as a supporter is asking the ombudsman to fulfil a task of providing a voice for the consumer, to be a consumer advocate. The consumer is expecting the ombudsman to support him/her in the complaints procedure:

'I expected the ombudsman to consider the evidence presented by myself and others to show that the authority failed in its duty. I wanted them to fairly compare this evidence with that presented by the authority. Then, to explain to me to what extent this evidence supported or failed to support my complaint and to give a reasoned view of the validity and strength of the complaint. [in other words] ... I hoped they would give me guidance and advice, I'd hope that the ombudsman would pick-up the baton from me and run with it.'

'I expected the ombudsman to take an impartial view and assess whether the procedures had been properly followed. I also hoped that the Council would have been ordered to be more transparent in their dealing with the public.'

'I needed help to force [the company] to do something rather than totally ignore our complaints for many months, [we want the ombudsman] get justice and get an apology for us, to intervene and apply common sense and put things right.' 
'I don't know really what to expect. Tell them off? Make them not do it again? I felt the company were so uninterested in my complaint that most people (especially vulnerable people or those with English as a second language) would never have got any sort of resolution. I hoped [the] Ombudsman would make them see the error of their ways.'

\subsubsection{Ombudsman as ally}

In this role, the ombudsman is expected to be a professional and competent partner who stands by the complainant's side. The complainant needs backup, support and reassurance:

'We expected the ombudsman to be independent and listen to our complaint. I felt [the local authority] was complacent and arrogant and not really listening to what we were saying, [and we wanted the ombudsman to] agree with us that we had a solid case.'

'I was looking for someone just to listen to the problems I was experiencing with the company and to possibly provide me with some advice as to what I could do further to help me communicate with [the company] in order for them to resolve the problem.'

'I expected that the problem is solved in a manner that non-lawyers can understand it, rather than using stereotypical legal (manipulated) reasons to solve the problem. Ordinary citizens cannot understand the legal "traps" and if the ADR body is just looking for a solution, guided by these legal traps then the consumer has zero chance.'

'I expected the ombudsman to recognise that the "remedy" offered by the council was unacceptable to me and instruct the council to offer a better solution, which would not have affected the council in any way, but simply not allowed them to bully me.'

'The ombudsman should investigate the complaint thoroughly and provide my family with the opportunity to put forward our concerns.'

This role has overlaps with the interpreter/advocate roles; however, in some cases, a distinct sense of needing an ally who is not a lawyer is apparent. This is explored further later in the paper.

\subsubsection{Ombudsman as instrument}

The complainant is aware of the ombudsman's powers and seeks to use them to his or her benefit. The individual expects to use the ombudsman as a tool, to open doors and reach an outcome for him or her. Some examples illustrate this role:

'I expected the Ombudsman to get [the company] to comply with the agreement I signed up to. I expected the Ombudsman to force [the company] to pay back the money owed to me and be able to bring [the company] to book to get a move on to sort out their mess quickly and get them to sort the problem asap like a general override to help the customer.'

'I thought the ombudsman would be able to access parts of the organization, which ordinary customers cannot reach and bring the energy supplier to justice and get the problem sorted out to my satisfaction.'

'I expected the ombudsman to assist me in obtaining my case files regarding events fabricated by the inspector and to also hold the council accountable for the complete lack of service provided in addition to their extremely rude behaviour.' 
'I expected them to get the Council to change their policy so that other people didn't fall foul of it. Also so that the Council would in future be taken seriously by local developers, builders and architects who currently lie in the application and development process knowing they can do so with impunity. I also hoped in the beginning that the Council would insist on my neighbours restoring the planting they had destroyed.'

'The ombudsman should step in promptly to stop this abuse of power and disregard for the accepted procedures by the district.'

These four roles can help make sense of the general and varied expectations respondents have of the ombudsman in the informal justice system.

\subsection{Assumptions about ombudsmen}

Respondents tend to expect ombudsmen to fulfil at least one of four described roles. The data show that respondents can alternate between the four role expectations throughout a complaint journey. Does this mean that people change their expectations alongside their experience of going through the ombudsmen's complaints process?

Initially, I approached the data with a method applied in the study of legal consciousness, asking questions about experiences, understandings and clusters of meanings (Ewick and Silbey, I998). The methodological approach worked well in the ombudsman context, although it is a different setting to the usual considerations of legal consciousness. The four models identified form part of expectations of an informal justice model. Unlike legal settings examined through the lens of legal consciousness, the ADR context does not have the equivalent foundation in the formal legal system. Prominent scholars of legal consciousness describe it as the ways law is experienced and understood by ordinary citizens' (Merry, I985). Ewick and Silbey explain the concept of legal consciousness in terms of people's experience of legality: 'In order to discover the presence and consequence of law in social relations, we must understand how legality is experienced and understood by ordinary people as they engage, avoid, or resist the law and legal meanings' (Ewick and Silbey, I998, p. 35). In the ombudsman context, we need to take a step back and examine how this informal justice system, and how justice in general, is experienced and understood.

People seem to have expectations of justice of an ombudsman and therefore expect them to act in a certain way. This could be based on people's legal socialisation (Trinkner and Cohn, 20I4) and encounters with the formal legal system (Gill and Creutzfeldt, forthcoming). The ombudsman, especially in the private sector, is not well known in justice systems of EU Member States (Hodges et al., 20I2). Therefore, we might anticipate that people's expectations are based on their existing expectations of the legal realm. This might explain the observed shift in expectations and its effect on perceptions of ombudsmen, as seen in my data. Four cases exemplify the shift in expectations during a complaint journey.

Case I reported a complaint about a local council:

'The service was good but I felt that I was not kept informed about what was happening and had to wait for a response. The case handlers' reasoning needed to be better explained and supported, the outcome seemed decided from the first response. A small sum of compensation was paid - not one that I agreed with but one, which the Ombudsman felt, was appropriate and I didn't. Having never been in this situation before I didn't know what to expect! The ombudsman either failed to understand the complaint, or, in my opinion was biased towards the xxx council.'

Case 2 complained about an energy company. The expectations of the ombudsman were to investigate honestly and thoroughly: 
'The staff was unhelpful and did not understand my problem. I was dissatisfied because it the process] was far from impartial, failed to answer pertinent questions and preferred conjecture to facts, the final decision was full of factual errors, which no effort was made to correct. I felt the service is not fit for purpose and is far from impartial; I was not being listened to.'

Case 3 an energy complaint that was ongoing. The respondent expected the ombudsmen to resolve the problem and to attempt to ensure that (the company's) procedure was spotlighted to prevent them behaving like this with other customers:

'I am fairly satisfied with the ombudsman. [The company] left a vulnerable disabled customer with a bill for nearly $£_{\mathrm{I}, 800}$. The best the ombudsman could come up with was for them to offer a written apology and for me to repay the debt according to my means. [The company] have issued the apology and it is an outrage and an insult. Overall I think the service is fine but it seems to me that the perceived protectors of the public good are either unwilling or unable to take appropriate action against the big six. I had hoped that the ombudsman would find in my favour but in my heart I was of the opinion that they where powerless and unwilling which was the outcome in the end. It is a hollow process with no teeth from my experience. I think people look to it with hope but the ombudsman appears to do nothing to tackle the behaviour and procedure of the companies.'

Case 4 is a PPI mis-selling claim. The respondent expected the ombudsman to resolve the issue as shown on television programmes. The respondent perceived the staff as unhelpful and was fairly dissatisfied:

'I started the process feeling satisfied as it went in my favour, this then changed to against me, then finally in my favour. Although the outcome was in my favour at the end, initially it was not until I asked many questions that were not answered and the ombudsman found in my favour.'

These examples show that people who go through an ombudsman process can change their perceptions throughout their complaint journey. As people are unsure of what to expect, their expectations are closely entwined with the outcome they receive. ${ }^{15}$

Summing up, the data have shown that there are no clear expectations people have of an ombudsman procedure. Rather, I propose that expectations can be grouped into roles; these may be based on users' experiences and expectations of the (formal) legal system they are accustomed to. However, these roles have no clear boundaries and can shift and change throughout a complaint as people's expectations are tested against their experience. The data demonstrate clearly that people are still very unsure about what to expect from this ADR model.

\section{Comparing people's expectations of the ombudsman}

The four role expectations of ombudsmen identified above are found throughout the dataset, whether relating to public or private ombudsmen and whether in Germany or the UK. There are, however, national distinctions in the ways in which the roles are described, especially the roles of instrument and ally. In this section, I explore these differences. The roles of advocate and interpreter are described in similar terms throughout the dataset. In other words, respondents are looking for

I5 The question of procedural justice is dealt with elsewhere (Creutzfeldt and Bradford, 20I6). 
support in communicating with, and understanding why, the company or local authority is not cooperating. The roles of ally and instrument, however, differ between the UK and Germany. I argue that this might be related to national characteristics that have been described as general legal culture and institutional availability.

Legal culture is a very complex concept (Sewell, 2005; Nelken, I996; 2010; Silbey, 2010) and is understood here as a 'system of symbols and meanings and their associated social practices' as they relate to the law (Silbey, 2010, p. 47I). In this paper, then, rather than taking the 'law first' approach (Sarat and Kearns, I993, p. 55), an exploration of legal culture (Sarat, 1977) is more suitable as an initial step to place expectations of the ombudsman model into context. This allows exploring, and linking, the 'richness and complexity of the interactions of the legal and the everyday' (Sarat and Kearns, I993, p.55). In other words, it can be seen as a foundation that informs people's expectations of both the formal and informal justice system. Whereas people usually have a clear set of expectations of what the formal legal system can provide, these are not as clear when it comes to the informal system. National distinctions, then, may have implications for the development and acceptance of ADR bodies throughout the EU.

The implicit assumptions are that external forces of 'sociocultural production' (de Certeau, I984, p. xiv) affect categories of similarly situated people in similar ways. In the context of this paper, I argue that people who deal with an ombudsman are influenced through the sociocultural environment of the legal culture they are accustomed to, building on Freidman's (I969, p. 34) definition of legal culture as 'the values and attitudes which bind the system together, and which determined the place of the legal system in the culture of the society as a whole'.

In the UK, the expectation that the ombudsmen fulfil the role of ally and instrument is expressed in narratives that are framed less legalistically, less formally: to 'fully investigate; the common man's last resort; to take over and bring the case to a conclusion; to sort things out for me'. I suggest that the differences that Blankenburg (I994) identifies between Germany and the Netherlands might also apply to Germany and the UK and this then relates to the way in which expectations are framed.

In Germany, the roles of ally and instrument tend to be framed in very legalistic terms. Terms used to describe expectations of the ombudsmen are: 'legal examination', 'legal positioning', 'pressure through the right letterhead', to 'give an official character' and 'to judge'. A further example is:

'I don't want to have to use a lawyer. My experience has shown that a letter of a lawyer moves a lot, this an average person cannot accomplish. Unfortunately, this is symptomatic of our times, that even when the consumer is in the right, you cannot achieve anything without a lawyer.'

These notions seem to reflect what has been described as a hierarchical German legal culture, reflected in the institutional infrastructure (Blankenburg, I994; I998). Although Blankenburg was comparing Dutch and German legal cultures, he describes the Dutch having an established network of avoidance infrastructure (ADR), which applies to the UK too:

'German legal culture offers less of an avoidance infrastructure than that of the Netherlands. Avoidance is part of the art of attorneys in Germany as well as in the Netherlands, but Dutch legal culture offers more alternatives and more pre court conflict institutions than German legal culture does' (Blankenburg, I994, p. 20).

Blankenburg focuses on institutional infrastructure (availability) as representing a key difference in legal culture. The institutional differences he identified are reflected in Germany and the UK, studied in this paper. 
The institutional set-up or availability of ADR bodies, despite being regulated through EU-wide standards, is very inconsistent (Hodges et al., 20I2). Those bodies that do exist have a variety of institutional structures and, on closer examination, national specificities. The fact that users of ombudsmen in Germany express their expectations in very legalistic and formal ways might then reflect the set-up of ombudsmen in Germany. All German ombudsmen are retired judges and all of their decision-making staff are lawyers. It is likely that, in this way, the system acquires acceptance and credibility from the German public. Although decisions are not binding through a (retired) judge issuing recommendations, they take on a legal character. In many ways, the German ombudsman model represents a level of legal formality that is absent in the UK ombudsman schemes. In the UK, the set-up of ombudsmen is very varied. Unlike in Germany, there is no clear profile of a person working as an ombudsman. There is no need for legal background and degrees. Rather, the ombudsmen and their staff are trained (only) in the applicable legal contexts.

The differences in the language used by German and British ombudsmen might reflect on the one hand general differences in national legal cultures, but also differences in the institutional set-up and availability of these ADR procedures. These two factors are almost certainly related.

\section{Conclusions}

This paper has examined distinct narratives of expectations of ombudsmen, as part of the informal justice system, in a comparative approach. The comparison emerged from a systematic study, with closed questions, intended to be analysed in a quantitative way. However, the study provided unexpected richness of data from the open-ended questions. The answers to these questions, when analysed qualitatively, identify common attitudes and expectations. They also reveal interesting national differences within a pattern of overall cross-cultural similarity.

The qualitative dataset allowed me to explore attitudes to justice among recent users of ombudsmen in Germany and the UK. Building on shared attitudes and commonalities, differences in ombudsmen procedures were explored in public and private settings, and across national boundaries. The comparison of expectations of recent ombudsmen users highlighted both differences and similarities.

The main differences that the dataset exposed were that citizens using a public-sector ombudsman to complain about the accountability of a public body tend to be seeking an apology and hoping for systemic change, whereas consumers complaining through a private-sector ombudsman are more focused on their individual dispute and are seeking a 'quick fix'. These findings are in line with the purpose of the respective bodies.

However, the study uncovered similarities, despite the differences in mandate, jurisdiction and responsibilities of the studied ombudsmen; the expectations of the roles that ombudsmen fill are the same. These findings ring true across sectors and countries in this study. These roles are: interpreter, advocate, ally and instrument. Although the roles overlap, this helps to shed light on general attitudes and evolving expectations of ombudsmen. On closer inspection, there are subtle differences that are reflected in the four roles. The main distinction is the use of language; in Germany, it is more legalistic in comparison with the UK. I argue that this might be related to two factors: what has been described as 'general legal culture' and institutional set-up and availability. The comparison between recent users of ombudsmen in different counties has therefore allowed me to identify developing narratives and patterns that could form the basis for future research into expectations of the informal justice system.

\section{References}

ABRAHAM, Ann (20I I) 'The Parliamentary Ombudsman and Administrative Justice: Shaping the next 50 Years'. JUSTICE, Tom Sargant Memorial Annual Lecture, London. Available at: <http://www. 
justice.org.uk/data/files/resources/304/Parliamentary-Ombudsman-and-Administrative-Justice. pdf>.

ADLER, Mike (2OI2) 'The Rise and Fall of Administrative Justice: A Cautionary Tale', Socio Legal Review 8

(2): $28-54$.

BERLIN, Christof (2014) Alternative Streitbeilegung in Verbraucherkonflikten: Qualitätskriterien, Interessen,

Best Practice. Nomos: Baden-Baden.

BLANKENBURG, Erhard (I994) 'The Infrastructure for Avoiding Civil Litigation: Comparing Cultures of

Legal Behavior in the Netherlands and West Germany', Law \& Society Review 28: 789-808.

BLANKenburg, Erhard (I998) 'Patterns of Legal Culture: The Netherlands Compared to Neighboring

Germany', American Journal of Comparative Law 46: I-4I.

Buck, Trevor, kirkham, Richard and thompson, Brian (20II) The Ombudsman Enterprise and

Administrative Justice. Burlington, VT: Ashgate.

CREUTZFeldT, Naomi (2013) 'The Evolution and Origins of Consumer Dispute Resolution Systems in

Europe' in Christopher Hodges and Astrid Stadler (eds) Resolving Mass Disputes: ADR and Settlement of Mass Claims. Cheltenham, UK and Northampton, MA, USA: Edward Elgar.

CREUTZFELDT, Naomi (20I4) 'How Important Is Procedural Justice for Consumer Dispute Resolution? A

Case Study of an Ombudsman Model for European Consumers', Journal of Consumer Policy 37(4): 527-546.

CREUTZFeldT, Naomi and BerLIN, Christof (2016) 'ADR in Aviation: European and National

Perspectives', Civil Justice Quarterly 35(2): I48-I6I.

CREUTZFeldT, Naomi and BRADFORD, Ben (2016) 'Dispute Resolution Outside of Courts: Procedural

Justice and Decision-Acceptance of Ombuds in the UK', Law \& Society Review, 50(4) forthcoming.

DE Certeau, Michael (1984) The Practise of Everyday life, translated by Steven F. Rendall. Berkeley:

University of California Press.

DeUtSChER, Bundestag (2015) 'Der Jahresbericht des Petitionsausschusses'. Available at: <https://www.

bundestag.de/blob/379464/8I87a86db3b9db4e9100050e4790ee23/der-jahresbericht-des-

petitionsausschusses--ausgabe-2015-data.pdf $>$

EwICK, Patricia and Silbey, Susan S. (I998) The Common Place of Law: Stories from Everyday Life. Chicago:

University of Chicago Press.

FRIEDMAN, Lawrence (I969) 'Legal Culture and Social Development', Law \& Society Review I: 29-44. Harlow, Carol and rawlings, Richard (2009) Law and Administration, 3rd edn. Cambridge, UK, and

New York: Cambridge University Press.

Hertogh, Marc (2013) 'Why the Ombudsman Does Not Promote Public Trust in Government: Lessons from the Low Countries', Journal of Social Welfare and Family Law 35(2): 245-258.

HODGES, Christopher and CREUTZFELDT, Naomi (2013) 'Implementing the EU Consumer ADR Directive'.

Available at: 〈http://www.fljs.org/sites/www.fljs.org/files/publications/Hodges-Creutzfeldt_o.pdf〉.

HOdGes, Christopher, BenÖHR, Iris and CReUtzFeldt-BAndA, Naomi (2012) Consumer ADR in Europe.

Oxford, UK and Portland, OR: Hart.

KIRKHAM, Richard (20I6) ‘The Implementation of the Consumer ADR Directive in United Kingdom' in

Pablo Cortés (ed.) The Transformation of Consumer Dispute Resolution in the European Union: A

Renewed Approach to Consumer Protection. Oxford: OUP.

Lind, E. Allan and TYLer, Tom (I988) The Social Psychology of Procedural Justice. New York and London:

Plenum Press.

MERRY, Sally Engle (I985) 'Concepts of Law and Justice among Working-Class Americans: Ideology as

Culture', Legal Studies 9: 59-69.

nelken, David (I996) Comparing Legal Cultures. Aldershot, Hants, England and Brookfield, VT:

Dartmouth Pub Co.

NELKen, David (2010) 'Using Legal Culture: Purposes and Problems', Journal of Comparative Law 5: I-5I. 
SARAT, Austin (I977) 'Studying American Legal Culture: An Assessment of Survey Evidence', Law \& Society Review II(3): 427-488.

SARAT, Austin and KEARns, Thomas (I993) 'Beyond the Great Divide: Forms of Legal Scholarship and Everyday Life' in Austin Sarat and Thomas Kearns (eds) Law in Everyday Life. Ann Arbor: University of Michigan Press.

Seneviratne, Mary (2002) Ombudsmen: Public Services and Administrative Justice. London: Butterworths LexisNexis.

SEWELL, William H. (2005) Logics of History. Chicago: University of Chicago Press.

SILBEy, Susan S. (20I0) 'Legal Culture and Cultures of Legality' in John R. Hall, Laura Grindstaff and Ming-Cheng Lo (eds) Handbook of Cultural Sociology. London and New York: Routledge Publishers, 470-479.

STERNLIGHT, Jean (2002) 'ADR Is Here: Preliminary Reflections on Where It Fits in a System of Justice', Nevada Law Journal 3: 289-304.

TRINKNer, Rick, and coHn, Ellen S. (20I4) 'Putting the "Social” Back in Legal Socialization: Procedural Justice, Legitimacy, and Cynicism in Legal and Nonlegal Authorities', Law and Human Behavior 38 (6): 602-6I 7 . 